\title{
RESEÑAS
}

\section{Pedro Iacobelli, Postwar Emigration to South America from Japan and the Ryukyu} Islands, London, Bloomsbury Academic, 2017, 280 pp.

This book is a fascinating study of the state-led Japanese and Ryukyuan migration to South America in the postwar era. Its careful analysis emphasizes the role of different state powers in planning, promoting and managing the trans-Pacific migration at both the point of departure and the point of arrival. It provides a comprehensive framework to investigate any government-driven emigration program in modern time. By examining the inter-play of the Japanese Government, the U.S. Civil Administration of the Ryukyu Islands and the Government of the Ryukyu Islands behind the Japanese and Ryukyuan migration to Bolivia during the formative years of the Japanese postwar nation, this book opens new possibilities in the transnational study of Japanese history during the Cold War era.

The first three chapters provide an overview of the Japanese migration to South America in the postwar era. Chapter one is a concise account of the history of the government's management of migration in modern Japan, which the author defines as "Political Migration History". It reviews how the Japanese government exercised its power over population by influencing the migration flows in both negative and positive manners in different contexts. Chapter two discusses a critical but often neglected aspect in the history of Japanese overseas migration, namely the discourse of overpopulation that served as a justification for Japanese overseas migration. The anxiety of overpopulation, as the author insightfully points out, was embraced by different interest groups to legitimize their migration agendas from the beginning the Japanese empire through the early years of the postwar era. Chapter three analyzes how Japan's postwar government attempted to relocate Japan as new and pacifist nation in the Western Block through Bolivian migration under the endorsement of the United States.

Chapters four to seven, on the other hand, focus on history of the Ryukyuan migration to South America in the postwar era. Chapters four and five place the Ryukyuan migration to Bolivia in the overall context of the global hegemony of the U.S. during the Cold War era. The American occupiers envisioned the relocation of the Ryukyuans to South America would strengthen the U.S. military control of the Ryukyu Islands and facilitate American appropriation of local resources. Chapter six explains how overseas migration served as a self-empowering strategy of the Ryukyuans to achieve their own mobility and political autonomy under the US. military occupation. The Government of the Ryukyu Islands, as chapter seven illustrates, actively participated in the promotion and management of the Ryukyuan migration, in order to meet the demand for emigration of the Ryukyuans themselves. By doing so, the government aimed to strengthen its own legitimacy as a representative state of the Ryukyuan people. Chapter eight, the concluding chapter, discusses the similarities between the Japanese Bolivian migration and the Ryukyuan Bolivian migration by focusing on the roles of the state. 
By paralleling and comparing the Japanese migration and Ryukyuan migration as two distinct experiences, however, this book leaves a few points to be further explored. As a colony-turned prefecture of the Japanese empire, the modern history of the Ryukyu Islands has profound political and cultural imprints of Japan since the 1870s. The migration of the Ryukyuans to different areas of the Pacific were closely interacted with Japanese colonial expansion. As the Ryukyu Islands continued to be a target of the de-imperialized Japan's territorial claim after WWII, readers would wonder how the migration policies in Japan and in the Ryukyu Islands in the postwar era intertwined, how the history of state-led Ryukyuan migration affected the relationship between Japan and the Ryukyu Islands when the latter were under the U.S. occupation, and whether the involvement of the Japanese government and social groups in Ryukyuan Bolivian migration fostered the reannexation of the Ryukyu Islands into the Japanese territory. Moreover, as Toake Endoh has demonstrated ${ }^{8}$, Japanese migration to South America before 1945, just like the postwar migration, was managed by Tokyo in many ways. Readers may wonder if the analytical model of "Political Migration History", well advanced in this book, can also be applied to Japanese and Ryukyuan emigration before 1945 .

Regardless of these questions, this book is one of the best works on the history of Japanese and Ryukyuan emigration in recent years. It is a well-researched study through a careful examination of multi-lingual and multi-national archives and sources. Through the history of migration, this study moves our understanding of the Cold War politics in East Asia beyond the region itself. It demonstrates the Japanese postwar nation and the U.S. occupation of Ryukyu Islands were developed hand in hand with American Cold War hegemony in South America and East Asia. It is a must read for historians and social scientists specializing in Japanese and Ryukyuan migration. The book will be also welcomed by scholars in any field of migration studies with an interest in the roles of the state.

SiDNEY X. LU

Michigan State University

\footnotetext{
${ }^{8}$ Toake Endoh, Exporting Japan: Politics of Emigration toward Latin America, Champaign, University of Illinois Press, 2009.
} 